\title{
Ukąszenie komara przeciwko enaktywistycznemu ujęciu doświadczeń cielesnych $^{*}$
}

\author{
Frederique de Vignemont \\ Instytut Jean-Nicod w Paryżu \\ frederique.de.vignemont[]ens.fr \\ Przekład: Przemysław Nowakowski
}

(Tekst oryginalny pt. „A mosquito bite against the enactive approach to bodily experiences” ukazał się w Journal of Philosophy 108 (4):188-204 (2011) ${ }^{14}$ )

Przekład zaakceptowano: czerwiec 2014; opublikowano: lato 2014.

\begin{abstract}
Abstrakt
Celem koncepcji enaktywistycznych jest zaproponowanie jednolitego ujęcia doświadczeń percepcyjnych w kategoriach aktywności cielesnych. Większość enaktywistycznych argumentów pochodzi z analiz doświadczeń wzrokowych (Noë 2004), jednak istnieje taki rodzaj świadomości, dla którego ujęcie enaktywistyczne wydaje się mniej kontrowersyjne, mianowicie doświadczenia cielesne. Po nakreśleniu schematu enaktywistycznego ujęcia doświadczeń dotykowych wskażę zarówno pojęciowe, jak i empiryczne problemy, jakim musi ono stawić czoła.
\end{abstract}

Słowa kluczowe: enaktywizm; doświadczenie cielesne; percepcja; działanie; dotyk.

Enaktywistyczne ujęcie doświadczeń cielesnych odrzuca klasyczną obliczeniową dychotomię między percepcją a działaniem ${ }^{15}$. Percepcja nie jest wyłącznie po to, by działać, a działanie po to, by postrzegać. Rzecznicy ujęcia enaktywistycznego argumentują w tym miejscu za silniejszą relacją konstytu-

\footnotetext{
* Jestem wdzięczna Nedowi Blockowi i Pierrowi Jacobowi za ich pomocne komentarze i wsparcie.

${ }^{14}$ Przekład publikowany za zgodą właścicieli praw do tekstu.

${ }^{15}$ Tego ujęcia bronią między innymi: Susan Hurley w Consciousness in Action (1998), J. Kevin O'Regan wraz z Alva Noë w „Sensomotoryczne ujęcie widzenia i świadomości wzrokowej” (2001/2008: 138-236); Noë w Action in Perception (2004). Evan Thompson w „Sensorimotor subjectivity and the enactive approach to experience" (2005: 407-427).
} 
tywnej współzależności. W tym ujęciu treść percepcyjna jest konstytutywnie zależna od zbliżonych do praw relacji zachodzących między sensorycznym wejściem a motorycznym wyjściem. Dlatego mówi się, że doświadczeń percepcyjnych nie da się oddzielić od cielesnej aktywności postrzegającego.

Enaktywiści traktują dotyk jako paradygmatyczny przykład percepcji, ponieważ treść naszej percepcji dotykowej jest konstytutywnie determinowana przez nasz akt eksplorowania kształtu przedmiotu własnymi palcami.

Wszystkie percepcje są podobne do dotyku w tym sensie, że doświadczenie percepcyjne nabywa treść dzięki sprawnościom cielesnym, którymi dysponujemy. To, co postrzegamy, zdeterminowane jest przez to, co robimy (lub co wiemy o tym, jak to zrobić) (Noë 2006: 1).

Dotyk nabywa treść przestrzenną - zaczyna reprezentować jakości przestrzenne - dzięki sposobom, w jakie łączy się z ruchem i naszym niejawnym rozumieniem istotnych, dotykowo-motorycznych zależności zarządzających naszymi interakcjami z przedmiotami (Noë 2006: 205).

Jakkolwiek to wzrok skupił najwięcej uwagi, wydaje się bardziej prawdopodobne, że ujęcie enaktywistyczne jest prawdziwe bardziej w przypadku doświadczeń dotykowych niż w przypadku doświadczeń związanych z jakimikolwiek innymi zmysłami (jak doświadczenia smakowe). Na przykład w dotyku haptycznym* system dotykowy nie jest pasywnym odbiorcą informacji cielesnych, ale charakteryzuje się aktywnością eksploracyjną. Jednak to, co może być prawdziwe dla dotyku haptycznego, który jest wewnętrznie aktywny, może być bardziej kontrowersyjne w przypadku dotyku pasywnego (na przykład odczucia komara na twojej skórze). Jeżeli dotyk miałby być modelem dla całej percepcji lub nieco mniej kontrowersyjną aplikacją ujęcia enaktywistycznego, wymaga on dokładniejszego zbadania.

Po nakreśleniu schematu enaktywistycznego ujęcia doświadczeń dotykowych wskażę zarówno pojęciowe, jak i empiryczne problemy, jakim musi ono stawić czoła. Podsumuję to tezą, że to, co robimy, nie determinuje tego, co czujemy.

\footnotetext{
* W badaniach nad dotykiem wyróżnia się kilka typów dotyku; jeden z tych typów, zwany dotykiem haptycznym, odnosi się do dotyku aktywnego, w którym organ dotykowy (najczęściej ręka) eksploruje, bada przedmiot. Alternatywnym względem haptycznego byłby dotyk pasywny, w trakcie którego mamy do czynienia z odczuwaniem np. rąk dotykających (najczęściej nieruchomego) organu. Jako ważną różnicę można wskazać to, że w dotyku haptycznym mamy do czynienia z udziałem propriocepcji i kinestezy, a w przypadku dotyku pasywnego mamy do czynienia jedynie z dotykiem [przyp. tłum.].
} 


\section{SCHEMAT ENAKTYWIWSTYCZNEGO UJĘCIA DOŚWIADCZEŃ DOTYKOWYCH}

W samym centrum koncepcji enaktywistycznych znajduje się dynamiczna, konstytutywna relacja między zmysłowym wejściem a motorycznym wyjściem. Według tego ujęcia jesteśmy zdolni śledzić ich wzajemną zależność. Zdolność ta osadzona jest w wiedzy proceduralnej: jak sposób naszego poruszania się wpływa na otrzymywane sygnały zmysłowe (lub jak ruch przedmiotów wpłynie na te sygnały). W tym sensie Hurley mówiła o „aktywnej percepcji”, a Noë opisywał percepcję jako pewną „ucieleśnioną aktywność”.

Należy jednak wziąć pod uwagę różnorodność ujęć, które obejmuje enaktywizm. W istocie niewiele jest wspólnego między [poszczególnymi] przedstawicielami ujęcia enaktywistycznego - poza twierdzeniem o wzajemnej zależności percepcji i działania. Jedną godną uwagi różnicą jest różnorodność explanand wśród ujęć enaktywistycznych. Uważa się, że istnieją co najmniej trzy zjawiska, które wymagają ujęcia w terminach enaktywizmu: (i) indywiduacja modalności percepcyjnych (na przykład wzrok vs słuch), (ii) fenomenologia percepcyjna (na przykład jak to jest postrzegać) i (iii) treść percepcyjna (na przykład treść reprezentacyjna). Po pierwsze argumentowano za tym, że każda modalność zmysłowa zależy od własnych, specyficznych wzorów wzajemnej dynamicznej zależności pomiędzy pobudzeniem zmysłowym a ruchem. Ten zbiór wzorców różni się na przykład w zależności od tego, czy przedmiot jest widziany, czy dotykany, a to indywiduuje różne modalności zmysłowe, tu: odróżnia wzrok od słuchu. Po drugie niektóre wersje ujęcia enaktywistycznego pretendują do wyjaśniania świadomości, a dokładniej jakościowej fenomenologii doświadczenia percepcyjnego. Przykładowo doświadczenie widzenia czerwonego pomidora zależałoby od proceduralnej wiedzy o sensorycznych efektach własnego ruchu względem światła. Wreszcie: większość koncepcji enaktywistycznych przyjmuje za swój cel wyjaśnienie intencjonalnej treści doświadczeń percepcyjnych, a zwłaszcza to, jak doświadczenia te reprezentują własności przestrzenne. Widzieć, że stół jest okrągły, to wiedzieć, że wygląda mniej lub bardziej eliptycznie w zależności od tego, gdzie względem niego się znajdujemy.

Nie jestem tu zainteresowana idiosynkrazjami różnych ujęć enaktywistycznych $^{16}$. Raczej zaproponuję różne sposoby przedstawienia enaktywistycznego spojrzenia na doświadczenia dotykowe i skoncentruję się na ujęciu najbardziej prawdopodobnym. Podążając za powyższymi rozróżnieniami, enaktywistyczne ujęcie doświadczeń dotykowych zmierza w kierunku następujących celów: (i) zindywiduowania modalności dotykowej (na przykład odróżnienia jej od modalności wzrokowej); (ii) wyjaśnienia fenomenologii wrażeń doty-

\footnotetext{
${ }^{16}$ Aby zapoznać się z przeglądem różnic między wersjami enaktywistycznych koncepcji widzenia, zob. Gangopadhyay i Kiverstein 2009: 63-73.
} 
kowych (na przykład świadomego wrażenia nacisku na moją skórę); (iii) wyjaśnienia przestrzennej treść doświadczeń dotykowych (na przykład wrażenia, że okrągły przedmiot dotyka mojej dłoni). W tym ostatnim przypadku enaktywiści muszą uwzględnić dwoistość treści doświadczeń dotykowych. W odróżnieniu od innych modalności dotyk dotyczy zarówno świata zewnętrznego, z którym jest w kontakcie, jak i własnego ciała, które jest w kontakcie ze światem zewnętrznym. Zatem enaktywistyczne ujęcie doświadczeń dotykowych musi pomieścić zarówno treść eksterocepcyjną, jak i interocepcyjną.

Problem jest jeszcze bardziej złożony: „dotyk” to termin tak pojemny, że można by nawet zaprzeczać temu, że odnosi się on do jakiejś odrębnej modalności zmysłowej. Z jednej strony istnieje dotyk aktywny. Jest on pierwotnie określany przez ruchy części ciała będącego w kontakcie z przedmiotem. Można wyróżnić trzy typy takich ruchów. Jedne to ruchy pasywne (na przykład twoja ręka poruszana przez kogoś innego). Inne są ruchami eksplorującymi, wolicjonalnie inicjowanymi przez postrzegającego (gdy na przykład identyfikujesz kontur przedmiotu). Niektóre ruchy wymagają wysiłku (między innymi podczas manipulowania i podnoszenia przedmiotu przy wysiłku mięśni). Z drugiej strony istnieje dotyk pasywny, który obejmuje wyłącznie sferę skóry. I tutaj znowu można odróżnić dotyk pasywny statyczny (jak nacisk kota na twoje kolana) oraz pasywny kinematyczny (na przykład poruszanie się komara na twojej skórze).

Z uwagi na ich interocepcyjną treść doświadczenia dotykowe są częściowo doświadczeniami cielesnymi lub - chcąc być bliżej terminologii enaktywizmu - ucieleśnionymi. Jednak tym, co ważne dla ujęcia enaktywistycznego, jest nie tyle ucieleśnienie percepcji, ile jej nierozerwalny związek z działaniem. Dyskusyjne jest, czy doświadczenia dotykowe zależą od ucieleśnionej aktywności. To prawda, że w dotyku haptycznym poruszam moim ciałem, aby uzyskać informacje o przedmiocie, a ruchy mojej ręki po jego powierzchni powodują zmiany wrażeń. Jednak czy można generalizować enaktywistyczne ujęcie doświadczeń haptycznych na wszystkie rodzaje doświadczeń dotykowych, a nawet bardziej ogólnie: doświadczeń cielesnych? W jaki sposób tak zwany pasywny rodzaj dotyku miałby być aktywny?

Zamierzam tutaj zastosować ujęcie enaktywistyczne do chwilowego dotyku pasywnego, który wydaje się w tym przypadku największym wyzwaniem. Wyobraźmy sobie, że czujemy krótkie, bezbolesne zetknięcie się czegoś z moim kolanem. Treść mojego doświadczenia nie jest zbyt bogata. Mogę nawet nie być w stanie rozpoznać, co mnie dotknęło. Jednak czuję, że zostałam krótko dotknięta $w$ moje kolano i nigdzie indziej. Co ugruntowuje tę moją fenomenologię i treść przestrzenną doświadczenia dotykowego? Jeśli ktoś zaproponuje przekonujące ujęcie enaktywistyczne tak ubogiego doświadczenia dotykowego, jest duża szansa na to, że będzie mógł tym samym zaoferować bardziej 
ogólne enaktywistyczne ujęcie doświadczeń cielesnych. Zobaczmy więc, jakie są możliwości. Jak się okazuje, zadanie nie jest łatwe.

\section{OCZEKIWANIA DOTYKOWO-MOTORYCZNE}

Jak już powiedziano, doświadczenia wzrokowe zależą od ruchów oka, a dotyk haptyczny od eksploracyjnych ruchów ręki. Jednak nie potrzebuję się poruszać, aby mieć doświadczenia dotykowe, jak w przypadku dotyku pasywnego. Jednakże zwolennik ujęcia enaktywistycznego może przyjmować, że ma to miejsce nawet $\mathrm{w}$ przypadku dotyku pasywnego i polega na opanowaniu wiedzy proceduralnej o dotykowych konsekwencjach potencjalnych ruchów (to znaczy zbieżności sensomotorycznych). Ważna jest nie cielesna ekspertyza w ramach wiedzy proceduralnej, a jedynie jej posiadanie. Na przykład wrażenie swędzenia opierałoby się na wiedzy, że jeśli podrapię się tam, gdzie zostałam ukąszona przez komara, to stymulacja zmniejszy się. Nikt nie potrzebuje drapać własnej nogi, by znać konsekwencje tego drapania. To samo można powiedzieć o wrażeniach dotykowych. Tym, co konstytuowałoby wrażenia dotykowe, jest nie to, co robisz, ale to, czego oczekujesz, że poczujesz, jeśli coś zrobisz. Jednak jaki rodzaj wiedzy proceduralnej jest konstytutywny dla dotyku pasywnego?

Pozwólmy sobie rozpocząć od dwóch możliwych oczekiwań dotykowomotorycznych ${ }^{17}$.

(1) Jeśli odsunę moje kolano od przedmiotu, z którym jest ono $w$ kontakcie, to przestanę otrzymywać sygnały dotykowe.

(2) Jeśli odsunę ten przedmiot moją ręka, przestanę otrzymywać sygnały dotykowe.

Tak podstawowe i niekontrowersyjne oczekiwania jak dotykowo-motoryczne przysparzają kilka problemów. Najbliższym odpowiednikiem widzenia byłoby oczekiwanie, że jeśli zamknę swoje oczy, to przestanę otrzymywać sygnały wzrokowe. Żaden przedstawiciel komputacjonizmu nigdy nie odrzucał tej prostej relacji przyczynowej zależności między widzeniem a otwieraniem/zamykaniem oka czy pomiędzy dotykiem a kontaktem cielesnym. Jednak nie wszystkie relacje przyczynowe między dotykiem a działaniem mieszczą się w ujęciu enaktywistycznym. Zgodnie z Hurley wzajemne zależności między percepcją i działaniem mogą być dwojakiego rodzaju. Są one instrumentalne, kiedy działanie stanowi jedynie środek do percepcji. Są nieinstru-

\footnotetext{
${ }^{17}$ Można by wysunąć sporo wątpliwości w kwestii dokładnej natury wiedzy sensomotorycznej (aby dokładnie zapoznać się z uwagami odnośnie do doświadczeń wzrokowych, zob. komentarze w: O’Regan i Noë 2001). Tutaj nie będę zajmowała się tymi ogólnymi problemami z ujęciem enaktywistycznym, lecz skoncentruję się na specyficznych problemach związanych z wiedzą dotykowo-motoryczną.
} 
mentalne, kiedy percepcja w całości lub częściowo opiera się na działaniach. Jedynie ten drugi rodzaj jest istotny dla ujęcia enaktywistycznego. Pytamy więc o to, który rodzaj oczekiwań sensomotorycznych spośród (1) i (2) przynależy odpowiednio do zależności instrumentalnych bądź nieinstrumentalnych. W przypadku widzenia ruch otwierania/zamykania oczu czyni doświadczenie wzrokowe możliwym lub niemożliwym, lecz jest to cecha wszelkiego rodzaju doświadczeń wzrokowych. Jako taka, nie może ona określać specyficznego opisu przeżycia ani szczególnej treści doświadczenia wzrokowego jako skutku otworzenia przeze mnie oczu. Również w przypadku dotyku ruch oddzielenia części ciała od przedmiotu (lub wejście w kontakt z przedmiotem) przerywa doświadczenia dotykowe, ale przerwałby każdy typ takich doświadczeń, niezależnie od tego, czy czułabym powierzchnię nierówną, czy gładką. Dlatego nie może on być czynnikiem indywiduującym w opisie moich dotykowych doświadczeń ani ich treści deskryptywnych. Co najwyżej ten typ zbieżności sensomotorycznych może indywiduować modalność zmysłową: widzenie konstytutywnie wymagałoby zamknięcia oczu w celu zatrzymania przepływu informacji, a dotyk konstytutywnie wymagałby przerwania kontaktu części ciała z przedmiotem w celu przerwania przepływu informacji. Wydaje się jednak, że większość zwolenników enaktywizmu wymaga tutaj czegoś więcej.

Na przykład stwierdziliby, że zbieżności dotykowo-motoryczne (1) mogą indywiduować przynajmniej cielesną treść przestrzenną. Jednak skąd mogę wiedzieć, że powinnam poruszyć właśnie kolanem? Występuje tu ryzyko błędnego koła podobne do tego naświetlonego przez Jacoba w związku z widzeniem (2008: 446-461). Ujęcie enaktywistyczne przyjmuje, że wiedza wzrokowo-motoryczna opiera się na wiedzy o tym, jak moje własne ruchy wykonywane w kierunku widzianego przedmiotu wpływają na to, jak postrzegam ten przedmiot. Jacob jednak zauważa, że aby oddziałać na przedmiot, trzeba najpierw być zdolnym do wyróżnienia i wybrania go spośród innych przedmiotów. Dlatego sama wiedza wzrokowo-motoryczna nie umożliwia nam indywidualizowania istotnych dla nas obiektów. Ta historia musi mieć dodatkową część, nie do opowiedzenia w terminach enaktywistycznych. Podobnie w przypadku dotyku nie jest jasne, w jaki sposób ktoś mógłby indywiduować część ciała na podstawie zbieżności dotykowo-motorycznych bez podobnego popadania w błędne koło. Wiedza dotykowo-motoryczna wymaga uprzedniego i niezależnego sposobu wyróżniania istotnych części ciała kontaktujących się z przedmiotem, jeśli ktoś chce uniknąć cyrkularnego ujęcia cielesnej treści przestrzennej.

Oczekiwania dotykowo-motoryczne (1) i (2) nie działają, jeśli mają konstytuować fenomenologię lub treść dotykowych doświadczeń. Problem jest jednak bardziej podstawowy i nie ogranicza się do tych dwóch przykładów. Wykładnia enaktywistycznego ujęcia treści doświadczeń dotykowych jest naprawdę trudna, szczególnie w zakresie treści interocepcyjnej. W odniesieniu do pewnych ujęć enaktywistycznych tym, co konstytuuje treść doświadczenia per- 
cepcyjnego, jest wiedza proceduralna, która daje dostęp do obiektywnych własności na podstawie relacji między własnościami perspektywicznymi a aktywnością cielesną. Na przykład stół jest okrągły (obiektywna własność bodźca niezależna od postrzegającego), ale jawi się nam jako eliptyczny (własność perspektywiczna, która jest sposobem, w jaki bodziec nam się pojawia). Zgodnie z teorią enaktywizmu nasze doświadczenie wzrokowe przedstawia stół jako okrągły, ponieważ wiemy, że jego własność perspektywiczna zmienia się w zależności od tego, jak poruszamy się względem obiektu (na przykład podchodząc do stołu). Jednak w tym ujęciu trudno dostrzec, w jaki sposób może zachodzić jakakolwiek zależność między dotykiem a działaniem dopóty, dopóki będziemy koncentrować się na interocepcyjnej treści dotyku. Kiedy czuję dotknięcie na swoim kolanie, podział na własność cielesną perspektywiczną i obiektywną wydaje się nie mieć sensu, jeżeli własności perspektywiczne zależą od przestrzennych relacji między postrzegającym a przedmiotem. Jeśli przedmiotem jest moje własne ciało, wówczas nie może być ono zablokowane na percepcję dotykową, nie można też zmienić własnej relacji przestrzennej ze swoim ciałem. Innymi słowy nie można zmienić przestrzennych warunków odczuwania własnego ciała. Mierząc się z tą trudnością, zwolennicy ujęcia enaktywistycznego mają dwa wyjścia: albo ograniczyć swoje ujęcie do eksterocepcyjnej treści doświadczeń dotykowych, albo zaoferować alternatywny typ enaktywistycznego ujęcia treści interocepcyjnej, który będzie różny od tego zaproponowanego dla treści eksterocepcyjnej.

I wreszcie: nawet jeśli nakreślone powyżej zbieżności dotykowo-motoryczne są satysfakcjonujące, mogą one nie działać dla każdego rodzaju dotyku i dlatego nie spełniają wymogów programu enaktywistycznego. Na przykład nie można ich łatwo odnieść do chwilowego dotyku. Kiedy doświadczam chwilowego dotknięcia na swoim kolanie, nie mogę odsunąć tego kolana od [dotykającego go] obiektu (ani też usunąć go z kolana), ponieważ ów obiekt zdążył już zniknąć. A gdyby mi się to udało, nie byłoby żadnej różnicy w stymulacji dotykowej, skoro sygnał dotykowy został już zatrzymany. Ogólnie mówiąc, trudno jest wyobrazić sobie wzajemną zależność percepcji i działania przy percepcji tak krótkotrwałej, że nie pozostawia ona czasu na działanie. Większość oczekiwań sensomotorycznych, aby mogły mieć sens, wymaga trwałych doświadczeń percepcyjnych. Jeśli obiekt [przyczyna] nie jest dłużej obecny, nie może być tutaj żadnych percepcyjnych konsekwencji. Dlatego też nie można tutaj mówić o żadnych zbieżnościach sensomotorycznych. Jeśli to prawda, to nie ma możliwości enaktywistycznego ujęcia chwilowych doświadczeń dotykowych (czy też wszelkich innych chwilowych doświadczeń percepcyjnych).

Jedynym wyjściem jest włączenie do ujęcia enaktywistycznego nie tylko wiedzy sensomotorycznej, ale również samej wiedzy motorycznej. Można argumentować, że to nie ma znaczenia to, że zbyt późno odsuwam swoje kolano od przedmiotu, który krótko mnie dotykał. To działanie nawet nie musi zostać wykonane, ono jedynie wymaga wyzwolenia przez sygnał dotykowy. Chęć 
ruchu konstytuowałoby doświadczenie percepcyjne niezależnie od cielesnego wykonania tego ruchu, jego sensorycznego sprzężenia zwrotnego, jak i utrzymującej się obecności wejść sensorycznych, które go wywołały. Wiedza proceduralna nie wymaga tego, by przedmiot, do którego się ją stosuje, był ciągle obecny. Wyobraźmy sobie, że ktoś opowiada mi o restauracji, którą bardzo lubił i którą niedawno zamknięto. Jeśli zapytam go, gdzie ta restauracja była, nadal będzie wiedział, jak się tam dostać (mimo że tej restauracji już tam nie ma). Podobnie mogę nadal oddziaływać na lokalizację bodźca dotykowego, mimo że ów bodziec nie jest już dostępny. Uczucie, że zostałam dotknięta w kolano, stanowi dla mnie wiedzę, jak dotrzeć do tego miejsca, w które mnie dotknięto ${ }^{18}$. W takim ujęciu treść przestrzenna doświadczenia bycia dotkniętą w kolano określona jest przez wiedzę proceduralną, jak dosięgnąć miejsca cielesnej stymulacji dotykowej. Odtąd będę traktować ten typ wiedzy proceduralnej jako przestrzenną „wiedzę, jak”19. To zastosowanie terminów wiedzy przestrzennej brzmi jak prawdopodobna hipoteza robocza dla ujęcia enaktywistycznego $\mathrm{z}$ dwóch powodó ${ }^{20}$. $\mathrm{Z}$ jednej strony ten rodzaj wiedzy proceduralnej wydaje się spójny z ujęciem enaktywistycznym („To, co postrzegamy, określane jest przez (...) to, co wiemy, jak to robić” (Noë 2006: 1). $\mathrm{Z}$ drugiej strony nie widzę żadnego alternatywnego rodzaju wiedzy proceduralnej, która mogłaby konstytuować chwilowy bierny dotyk.

Reasumując, połączenie między dotykiem a aktywnością cielesną powinno być tak oczywiste, że niewymagające odpowiednich badań; w rzeczy samej powinno nam pomóc lepiej zrozumieć (mniej oczywiste) enaktywistyczne ujęcie widzenia. Jednakże może to być prawdziwe jedynie dla dotyku haptycznego i jedynie dla jego treści eksterocepcyjnej. Enaktywiści nadal muszą sformułować odpowiednie ujęcie związku między dotykowymi doświadczeniami a działaniem w odniesieniu do chwilowego dotyku pasywnego, a to nie jest łatwe zadanie. Mogą argumentować, że jest to spowodowane właśnie tym,

\footnotetext{
${ }^{18}$ Jeżeli dosięgam miejsca na ciele, w które zostałam dotknięta, i kładę w tym miejscu palec, wówczas otrzymuję z tego samego miejsca sygnał dotykowy. W tym drugim przypadku wystąpią dotykowe konsekwencje.

${ }^{19}$ Aby zapoznać się ze szczegółową charakterystyką pojęcia cielesnej „wiedzy, jak”, zob. Siewart 2005: 270-94.

${ }^{20}$ Ktoś może jednak argumentować, że przestrzenna treść cielesnych doświadczeń musi być determinowana przez ruchy tej konkretnej doświadczanej kończyny. Na przykład doświadczenie, że moje kolano jest dotykane, powinno być determinowane jedynie przez ruchy mojego kolana. Jest wręcz przeciwnie: ruchy wskazujące i sięgające wykonywane są tą częścią ciała, która nie jest reprezentowana w treści dotykowej, to znaczy rękę. Czy ten rodzaj ruchu należy z tego powodu pominąć? To byłoby zbyt restrykcyjne. Większość działań, które można wykonać w stronę własnego ciała, to ruchy ręki, i jeśli pominie się je jako nieistotne, to poza nimi nie pozostanie już wiele ruchów. Ponadto istnieją części ciała, które pozostają nieruchome, a jednak możemy doświadczyć tego, że są one dotykane. Zatem można by sądzić w odniesieniu do reszty ciała, że treść przestrzenna doświadczenia dotykowego zależy od wiedzy proceduralnej dotyczącej części ciała, która jest dotykana.
} 
że związek z działaniem jest tutaj tak słaby i wskutek tego treść takich doświadczeń staje się dość uboga. To może być prawda. Niemniej jednak, aby ujęcie enaktywistyczne było prawdziwe, musi istnieć przynajmniej jeden typ funkcjonujących jak reguły związków z działaniem, jeśli w ogóle mamy do czynienia z jakimiś doświadczeniami dotykowymi. Sugerowałabym, że najbardziej prawdopodobnym sposobem określenia enaktywistycznego ujęcia doświadczeń dotykowych jest ujęcie w kategoriach ruchów sięgania w stronę tego miejsca na ciele, które zostało dotknięte. Jednak przekonamy się za chwilę, że pogląd taki napotyka na poważne trudności w konfrontacji z literaturą empiryczną dotyczącą doświadczeń cielesnych. Pokażę, że działanie i doświadczenia dotykowe są raczej niezależne niż wzajemnie zależne oraz że można je oddzielić w przypadkach zarówno patologicznych, jak i normalnych.

\section{ODRÓŻNIAJĄC DOŚWIADCZENIA CIELESNE OD PRZESTRZENNEJ „WIEDZY, JAK”}

Jeden z najmocniejszych argumentów przeciwko enaktywistycznemu ujęciu widzenia pochodzi z neuropsychologicznego odróżnienia między ataksją optyczną a agnozją wzrokową ${ }^{21}$. Przykład: cierpiącej na agnozję wzrokową pacjentce DF zaprezentowano zbiór rozmaitych kwadratów i prostokątów. DF, gdy wymagano od niej, by dopasowała szerokość tych prostych form geometrycznych przez skalowanie odległości między jej kciukiem a palcem wskazującym (to znaczy przez niewerbalny, manualny raport) ${ }^{22}$, działała losowo. W przeciwieństwie do tej dysfunkcji potrafiła dokładnie uchwycić owe klocki. Odwrotny wzorzec wykonań zaobserwowano u pacjentów z ataksją optyczną. Przypadki te pokazują, że można doświadczać wzrokowo przedmioty bez jednoczesnej zdolności wykonania dotykowych działań z ich użyciem - i vice versa. Oznacza to, że świadomość wzrokowa może funkcjonować niezależnie od kierowanych wzrokowo działań [manualnych].

Podobnych dowodów przeciwko enaktywistycznemu ujęciu widzenia dostarczają badania nad jednostkami zdrowymi. Odkryto, że działanie może być odporne na iluzje wzrokowe takie jak Müllera-Layera, Ponzo, Titchenera, iluzja pustej twarzy. W przypadku tej ostatniej wklęsła (bądź pusta) maska twarzy postrzegana jest jako normalna, wypukła (wystająca) twarz. Odkryto, że

\footnotetext{
${ }^{21}$ Aby zapoznać się z wyczerpującym przeglądem literatury, która wspiera tak zwany model percepcji-działania dla widzenia, zob. Milner i Goodale 1995/2008; Jacob i Jeannerod 2003. Obszerna dyskusja nad istotnością tego typu dowodów empirycznych dla ujęcia enaktywistycznego w: Jacob 2008; Block 2005: 259-72; Clark 2008.

${ }^{22}$ Niektóre ruchy rąk można uznać za raporty percepcyjne. Na przykład pokazano, że działania leżące u podstaw procesu skalowania odległości pomiędzy kciukiem a palcem wskazującym bardzo się różnią w zależności od tego, czy odnoszą się do sądów percepcyjnych, czy do wizualnomotorycznego zadania chwytania (Jeannerod 1997).
} 
gdy poprosić badanych, by szybkim ruchem strącili magnes z nosa maski (tak jakby tam był mały owad), nie kierują oni ruchów palca do miejsca, gdzie im się prezentuje nos (to znaczy do wypukłego nosa). Natomiast kierują je ku faktycznie umiejscowionemu celowi w pustej twarzy, który jest oddalony o osiem cali od lokalizacji postrzeganej. Innymi słowy, treść doświadczenia wzrokowego twarzy nie odpowiada kierowanym wzrokowo ruchom w kierunku twarzy. Potraktowano to jako dowód na to, że treść doświadczeń wzrokowych (na przykład wypukła twarz) jest rozbieżna z treścią widzenia zorientowanego na działanie (jak pusta twarz). To, co widzimy, nie jest determinowane przez to, co robimy, ani przez to, co wiemy o tym, jak robimy.

Czy istnieje równoważne świadectwo empiryczne przeciwko enaktywistycznemu ujęciu doświadczeń cielesnych? Odpowiedź brzmi: $\operatorname{tak}^{23}$. Na podstawie podziału między dotykowymi, propriocepcyjnymi doświadczeniami z jednej strony a przestrzenną „wiedzą, jak” z drugiej zarówno u pacjentów, jak i zdrowych jednostek chcę argumentować przeciwko enaktywistycznemu ujęciu: (i) fenomenologii doświadczeń cielesnych i (ii) przestrzennej treści doświadczeń cielesnych.

\section{III.1. Działanie bez wrażeń}

Ale ja tego nie rozumiem. Coś tutaj przystawiasz, niczego nie czuję, a jednak trafiam tam palcem. Jak to się dzieje ${ }^{24}$ (Paillard, Michet i Stelmach 1983: 550).

Pacjentka, która miała zasłonięte oczy, zdumiona jest własną zdolnością do wskazania na swojej ręce miejsca, gdzie ją dotykano, mimo że w ogóle nie czuła tego dotyku. Cierpi na coś, co w literaturze neuropsychologicznej nazywane jest „tępym czuciem” (wrażenie braku czucia, ścierpnięcia) (a także „ślepym dotykiem”). W następstwie uszkodzeń korowych lub podkorowych pacjenci z tępym czuciem stają się całkowicie znieczuleni po swojej prawej stronie. Są zupełnie pozbawieni doświadczenia dotyku. Nie są $\mathrm{w}$ stanie śledzić, lokalizować ani opisać bodźca dotykowego na swojej prawej ręce, podobnie jak nie potrafią wskazać na rysunku przedstawiającym rękę miejsca, w którym zadziałał bodziec, nawet w stanie wymuszonego słownie wyboru. Interesujące jest to, że mimo ich oczywistego stanu tępego czucia potrafią - ku własnemu zaskoczeniu, realizując polecenie - poprawnie poprowadzić swoją drugą rękę w dane miejsce, gdzie ich dotknięto. Cielesne ruchy badanych nie wpływają na poprawę wykonania zadania podczas lokalizacji werbalnej. Kiedy pacjenci proszeni są o jednoczesne słowne zlokalizowanie oraz wskazanie

\footnotetext{
${ }^{23}$ Odnośnie do pacjentów z tępym czuciem (numbsense) zob. Paillard, Michet i Stelmach 1983): 548-51; podobnie Rossetti, Rode i Boisson 1995: 506-10. Odnośnie do opisu KE i JO zob. Aenema i in. 2009: 1615-1620.

${ }^{24}$ Raport dotyczący pacjentki cierpiącej na tępe czucie.
} 
miejsca, w które zostali dotknięci, obie ich reakcje okazują się błędne. W dodatku mogą być nieświadomi położenia własnej ręki, a jednak być w stanie precyzyjnie do niej sięgnąć. Co ciekawe, ten rodzaj dysocjacji znany był Merleau-Ponty’emu. Opisał on przypadek pacjenta Schneidera, który nie był w stanie wskazać miejsca, w które ukąsił go komar, a jednocześnie potrafił podrapać się w nogę tam, gdzie został ukąszony (1945/2001: 131-139).

Skoro pacjenci z tępym czuciem drapią się w nogę po tym, jak zostali w nią ukąszeni, muszą dysponować pełnymi informacjami sensomotorycznymi dotyczącymi sięgania do swojej nogi, drapania się w nią oraz wyników tych działań. Jednakże pomimo owej wiedzy sensomotorycznej niczego nie czują. Mamy tutaj oczywisty przypadek całkowitego braku fenomenologii dotykowej i propriocepcyjnej przy zachowanej przestrzennej „wiedzy, jak”. Z tego względu przykład tępego czucia pokazuje, że przestrzenna wiedza proceduralna (wraz z praktykowaniem jej) per se nie jest wystarczającym warunkiem dla fenomenologii dotykowej i propriocepcyjnej.

\section{2. Działanie bez percepcji, percepcja bez działania}

Jak powiedziano wcześniej, niektóre wersje enaktywizmu mają na celu raczej wyjaśnienie tego, jak doświadczenia percepcyjne zaczynają reprezentować własności przestrzenne, niż tego, jak to się dzieje, że zaczynają one dysponować świadomą treścią fenomenalną. Stąd można by argumentować, iż świadectwo związane z przypadkiem tępego czucia nie ma znaczenia dla tych wersji enaktywizmu. Większym wyzwaniem są dla nich przypadki pacjentów KE i JO, którzy posiadają doświadczenia dotykowe, które jednak oderwane są od przestrzennej „wiedzy, jak” w taki sam sposób, w jaki doświadczenia wzrokowe są rozdzielone w ataksji optycznej czy agnozji wzrokowej.

Zarówno KE, jak i JO potrafi świadomie czuć dotyk. Ponadto oboje umieją prawidłowo zgłosić i wskazać lokalizację widzianego celu. Jednak kiedy proszeni są o wskazanie miejsca, w które ich dotknięto, objawiają zaskakującą podwójną dysocjację. Pacjentów tych poproszono o wskazanie miejsca na dłoni, w które ich dotknięto (zadanie dotykowo-motoryczne), lub o wskazanie miejsca bodźca dotykowego na obrazkowej mapie ich dłoni (abstrakcyjne, oddzielne raporty percepcyjne). Okazało się, że JO nie potrafiła poprawnie wskazać miejsca na mapie dłoni, podczas gdy w odniesieniu do własnej dłoni wykonywała zadanie poprawnie. W przeciwieństwie do niej KE nie potrafił wskazać miejsca na własnej dłoni, za to z powodzeniem - na mapie dłoni. W żadnym z tych przypadków przestrzenna treść doświadczeń dotykowych nie odpowiada posiadaniu (lub jego braku) przestrzennej „wiedzy, jak”. JO doświadcza tego, że jest dotykana, ale nie potrafi powiedzieć, w którym miejscu. Doświadcza jedynie dotyku „gdzieś tam”, bez ściśle określonej treści przestrzennej. Jednak podobnie jak pacjenci z tępym czuciem, precyzyjnie lokali- 
zuje miejsce dotyku na swoim ciele. Mimo tego jej przestrzenna „wiedza, jak” nie wystarcza do tego, aby jej doświadczenie dotykowe posiadało treść przestrzenną. Dla odmiany KE doświadcza i zgłasza to, że jest dotykany w rękę w określonym miejscu, ale nie jest w stanie do tego miejsca sięgnąć. Stąd nie istnieje tutaj przestrzenna „wiedza, jak”, która gwarantowałaby przestrzenną treść doświadczenia dotykowego, a doświadczenie to musi posiadać inne podłoże ${ }^{25}$. Przypadek JO pokazuje, że przestrzenna „wiedza, jak” per se nie jest wystarczającym warunkiem dla dotykowej treści przestrzennej, zaś przypadek KE wskazuje na to, iż nie jest to warunek konieczny.

Podsumowując: dysocjacje te pokazują, że informacja przestrzenna w systemie sensomotorycznym może różnić się od informacji przestrzennej w systemie percepcyjnym. Pozwala to wysnuć wniosek, że system sensomotoryczny i percepcyjny nie są wzajemnie redukowalne. Stanowią dwa odrębne systemy, jeden zaangażowany $\mathrm{w}$ działanie, drugi - $\mathrm{w}$ doświadczenia percepcyjne. Rozdział między dwoma rodzajami informacji przestrzennej specyficznymi dla każdego z systemów może stać się jeszcze jaśniejszy w kontekście iluzji związanych z ciałem u osób zdrowych.

\section{III.3. Iluzoryczna treść przestrzenna}

Jeżeli przestrzenna „wiedza, jak” zapewnia treść przestrzenną doświadczeń percepcyjnych, to powinna umożliwić wyjaśnienie, dlaczego treść ta staje się iluzoryczna u osób zdrowych. Co prawda, jak już powiedziano wcześniej, okazało się, że działanie może być odporne na iluzje wzrokowe. Zobaczymy teraz, że iluzji związanych $\mathrm{z}$ ciałem nie można także wyjaśnić za pomocą błędnej informacji zakodowanej w przestrzennej „wiedzy, jak”. Opiszę tutaj jedynie przypadek Iluzji Gumowej Ręki (IGR), ale podobne wyniki przynoszą iluzje wibracyjno-dotykowe (wibracja ścięgna mięśnia dwugłowego ramienia wywołuje iluzoryczne doświadczenie kinestetyczne rozciągania się ramienia) ${ }^{26}$.

\footnotetext{
${ }^{25}$ Enaktywista mógłby odpowiedzieć, że nie ma tutaj żadnego dowodu na niedobór przestrzennej „wiedzy, jak” u KE. Istnieje jedynie dowód na niedobór w przestrzennym wykonaniu motorycznym, a to nie ujawnia konsekwentnie deficytów w samej tej wiedzy. Jeżeli tak, wówczas dotykową treść przestrzenną można by ująć w terminach przypuszczalnie zachowanej przestrzennej „wiedzy, jak”. To wytłumaczenie nie brzmi jednak przekonująco. Pacjent KE nie wykazuje żadnego motorycznego niedoboru, o czym świadczy jego zachowana zdolność do wskazywania na mapie dłoni lub neutralnych celów wizualnych. Wyników tych nie można wyjaśnić ani przez deficyty propriocepcyjne, ani pamięciowe. Podczas eksperymentu ręce pacjentów były pasywnie przemieszczane $\mathrm{w}$ inne miejsce, ponadto proszono ich o przywrócenie rąk do poprzedniej pozycji po dwóch sekundach. Wykonanie tego propriocepcyjnego zadania przez KE było podobne do wykonania JO. Wydaje się, że można tu założyć istnienie u KE deficytów w przestrzennej „wiedzy, jak”, co tłumaczy jego słabe wykonanie motoryczne podczas wskazywania swojej własnej dłoni.

${ }^{26}$ Aby zapoznać się z opisem standardowej Iluzji Gumowej Ręki, zob. Botvinick i Cohen 1998: 756. Opis standardowej iluzji wibracyjno-dotykowej - zob. Lackner i DiZio 2000: 279-88. Odporność na
} 
W Iluzji Gumowej Ręki (IGR) uczestnicy eksperymentu siedzą przy stole, na którym każdy z nich kładzie swoją lewą rękę, schowaną za ekranem. Następnie proszeni są o skupienie wzroku na gumowej [atrapie] dłoni znajdującej się przed nimi, a eksperymentator jednocześnie stymuluje dłoń badanego oraz gumową przy pomocy dwóch pędzelków. Po krótkiej chwili większość badanych twierdzi, że czują dotyk pędzelka w miejscu, w które - jak widzieli dotykana była dłoń gumowa. Co bardziej zaskakujące, niektórzy z nich czują, jakby gumowa ręka była ich własną. Na poziomie behawioralnym badani twierdzą, że ich własna dłoń była [położona] bliżej gumowej niż w rzeczywistości. Dzieje się tak tylko wtedy, gdy obie dłonie znajdują się w tej samej pozycji i są stymulowane jednocześnie.

Ujęcie enaktywistyczne mogłoby teraz wyjaśnić iluzję w terminach błędnej przestrzennej „wiedzy, jak”. Wyjaśnienie mogłoby przebiegać następująco: badani mają wrażenie, że ich własna dłoń znajduje się bliżej gumowej, ponieważ zostali wprowadzeni w błąd tak, by mogli się spodziewać, że jeżeli dosięgną miejsca blisko gumowej atrapy, to dotkną swojej dłoni. Jednak ostatnie wyniki badań przeczą takiemu wyjaśnieniu IGR. Okazało się, że badani prawidłowo kierowali swoją dłoń ku swojej drugiej dłoni, która była dotykana, nie zaś ku dłoni iluzorycznej, jak twierdzili. Ich ruchy sięgające nie były podatne na iluzję. Podobnie kiedy wykonywali ruch odwrotny (czyli gdy kierowali dłoń dotykaną w stronę swojej drugiej dłoni), posiadali prawidłową „wiedzę, jak” dotyczącą położenia ich ręki. Całkowity brak iluzji potwierdzono również w oburęcznej wersji eksperymentu, gdzie badani musieli chwycić znajdujący się przed nimi patyk. I znowu ich ruchy cielesne ujawniły prawidłową informację przestrzenną dotyczącą relacji między obiema rękami, podobnie jak zastosowanie „wiedzy, jak” względem ich prawidłowego ułożenia. Kiedy jednak po raz drugi poproszono badanych o dokonanie percepcyjnego sądu dotyczącego położenia ich dotykanej dłoni już po jej poruszeniu, wciąż byli podatni na IGR i w dalszym ciągu mieli wrażenie, że ich własna dłoń znajduje się bliżej gumowej atrapy niż w rzeczywistości.

Chociaż badani doświadczali nadmiernej bliskości swojej dłoni względem gumowej, jednak wiedzieli, gdzie się znajduje ta pierwsza, kiedy proszono ich o poruszenie nią. Z tego względu IGR nie można wyjaśniać za pomocą nieprawidłowej „wiedzy, jak”. Iluzorycznej treści przestrzennej doświadczenia ciała nie określa odporna na iluzję przestrzenna „wiedza, jak”, która pozostaje właściwym odczuciem pozycji dotykanej dłoni.

Podsumowując: u zdrowych osób, podobnie jak i u pacjentów, treść przestrzenna doświadczeń dotykowych i propriocepcyjnych może być oderwana od przestrzennej informacji zakodowanej w przestrzennej „wiedzy, jak” wy-

działanie iluzji wibracyjno-dotykowej wykazano w: Kammers, der Ham i Dijkerman 2006: 243036. Odporność na działanie Iluzji Gumowej Ręki wykazano w: Kammers i in. 2009: 204-11. 
korzystywanej do sterowania ruchami sięgania i wskazywania. Pacjenci z tępym czuciem stanowią wręcz ilustrację możliwości zachowania „wiedzy, jak” bez żadnych skojarzonych z nią wrażeń dotykowych. Z tego względu wydaje się, że przestrzenna „wiedza, jak” jako pozyskiwana poprzez ruchy sięgania, wskazywania i chwytania nie jest ani wystarczająca, ani konieczna dla doświadczeń cielesnych.

\section{DYLEMAT}

W odniesieniu do dotyku, podobnie jak wzroku, te różne przypadki rodzą interesujące pytania co do podejścia enaktywistycznego. Wydaje się, że na tym etapie staje ono przed pewnym dylematem. Mówiąc w skrócie: jeżeli enaktywistyczne ujęcie doświadczeń cielesnych ma się opierać na kategoriach przestrzennej „wiedzy, jak”, wówczas będzie fałszywe, ponieważ przestrzenna „wiedza, jak” jest odrębna względem doświadczeń cielesnych. Jeżeli podejście enaktywistyczne nie będzie ujmowane w kategoriach przestrzennej „wiedzy, jak”, w takim razie nie będzie jasne, jakiego rodzaju nastawienia sensomotoryczne mogłyby zapewnić zarówno eksterocepcyjną, jak i interocepcyjną treść przestrzenną doświadczeń dotykowych dowolnego rodzaju, włącznie z ciągłym ruchem pasywnym. Przedstawię pokrótce dwa aspekty tego dylematu.

Z jednej strony zwolennicy podejścia enaktywistycznego charakteryzują treść przestrzenną doświadczeń dotykowych w terminach przestrzennej „wiedzy, jak” odpowiadającej dotkniętemu miejscu na ciele (jak do niego dosięgnąć lub jak nim poruszyć). Widzieliśmy jednak, że ujęcie enaktywistyczne zostało tutaj zakwestionowane przez serię wyników empirycznych, które pokazują, że w przeciwieństwie do tego, co przewiduje to ujęcie - doświadczenia dotykowe są odrębne od działań obserwatora. Co prawda posiadanie prawidłowej „wiedzy, jak” nie gwarantuje tego, że osoba będzie świadomie czuła dotyk (jak w przypadku tępego czucia). Nie gwarantuje również tego, że przestrzenna treść doświadczeń cielesnych będzie właściwa (jak w przypadku pacjentki JO oraz Iluzji Gumowej Ręki). Jednakże brak przestrzennej „wiedzy, jak” nie oznacza automatycznie ani tego, że dana osoba nie będzie miała doświadczenia cielesnego, ani tego, że jej doświadczenie cielesne nie będzie obejmowało treści przestrzennej (jak w przypadku pacjenta KE). Wyniki te są trudne do pogodzenia z podejściem enaktywistycznym, jeżeli ma ono na celu wyjaśnienie doświadczeń dotykowych w terminach wiedzy proceduralnej zaangażowanej w sięganie, wskazywanie czy drapanie własnego ciała. To, co czujemy, nie jest wyznaczane przez to, co robimy, ani przez to, co wiemy, jak robić.

Z drugiej strony - zwolennicy podejścia enaktywistycznego umniejszają rolę przestrzennej „wiedzy, jak” zaangażowanej w omawiane ruchy jako nieistotne dla enaktywistycznego ujęcia doświadczeń cielesnych. W świetle tego 
twierdzą, że interesuje ich to, co znajduje się u podłoża doświadczeń percepcyjnych, a nie powód, dla którego one zachodzą ${ }^{27}$. Dlatego też odrzucają takie ruchy jako jedynie „praktyczne konsekwencje” doświadczeń cielesnych. Powiązanie percepcji z tego rodzaju działaniami uważają za wyłącznie instrumentalne. Stąd nie stanowi zaskoczenia fakt, że tego rodzaju przestrzenna „wiedza, jak” jest niezależna i rozdzielna względem doświadczeń cielesnych. Jeżeli jednak zwolennikom poglądu enaktywistycznego zależy na wykazaniu, że przestrzenna „wiedza, jak” nie angażuje właściwego dla doświadczeń cielesnych rodzaju wiedzy sensomotorycznej, w takim razie zmuszeni są zmierzyć się z kilkoma trudnościami.

Na początku muszą wyjaśnić, dlaczego ten typ relacji między percepcją a działaniem jest raczej instrumentalny niż konstytutywny. Dlaczego doświadczenia percepcyjne nie mogą być ugruntowane w powodach, dla których zachodzą? Nie jest jasne, w jaki sposób przeprowadzić podział między „prawidłowym” a „nieprawidłowym” rodzajem wiedzy proceduralnej. Jak już wspomniano, enaktywista może odrzucić [znaczenie] ruchów sięgających i wskazujących, ponieważ nie wpływają one na dotykową treść w taki sposób, jak odwracanie głowy wpływa na treść wzrokową. Może to być prawdziwe w odniesieniu do ruchów sięgania, wskazywania i chwytania, ale nie ruchów drapania się, kiedy to ma miejsce czytelna, odpowiadająca mu konsekwencja sensoryczna (która polega na tym, że kiedy ktoś drapie się w miejsce, w które został ukąszony, stymulacja zmniejsza się). A jednak pacjent Merleau-Ponty'ego, Schneider nie miał żadnego świadomego doświadczenia swędzenia, chociaż potrafił podrapać się w nogę w miejscu, gdzie go swędziała. Jeżeli tego typu zbieżność sensomotoryczna nie mieści się w zestawie wzorców zależności między stymulacją a ruchem, które konstytuują doświadczenie swędzenia, wówczas trudno stwierdzić, co $\mathrm{w}$ takim razie by się miało w nim mieścić. $\mathrm{Z}$ drugiej strony nie jest oczywiste, że enaktywizm mógłby zbagatelizować wiedzę proceduralną, której nie można wyrazić w terminach sensomotorycznych. Rozważmy doświadczenie błysku światła. Jakie jest stanowisko enaktywizmu wobec czasowej treści doświadczenia wzrokowego (to znaczy doświadczenia krótkotrwałości błysku)? Nie mamy tu do czynienia z odpowiednim oczekiwanym zmysłowo sposobem, w jaki czyjeś ruchy wpłyną na błysk światła, jeżeli błysk ten należy już do przeszłości. Co więcej, nie można odwołać się do kontrfaktyczności typu: „gdyby obiekt wizualny nadal był tutaj i gdybym zrobił $x$, wówczas zaszłaby wizualna konsekwencja $y$ ". To by rzeczywiście nie odnosiło się do krótkotrwałości bodźca wzrokowego. Z tego powodu wyjaśnienia enaktywistyczne muszą czasami uwzględniać wiedzę proceduralną przy braku możliwej modyfikacji sygnału zmysłowego. I jeśli jest to prawdziwe dla treści czasowej, to dlaczego ma nie być prawdziwe również dla treści przestrzennej? Szczególnie że enaktywista zostaje z pustymi rękami bez żad-

\footnotetext{
${ }^{27}$ Odnośnie do tego sposobu argumentacji zob. np. Noë 2010: 245-56.
} 
nego sensomotorycznego ujęcia przestrzennej treści doświadczeń cielesnych. Jak powiedziałam na początku, nie jest jasne, o jakich zbieżnościach sensomotorycznych mowa w przypadku dotyku biernego, zwłaszcza wtedy, gdy dotyk jest szczególnie krótkotrwały. Nie można tak po prostu podkreślać znaczenia działania $\mathrm{w}$ doświadczeniach cielesnych; należy przedstawić szczegółowe stanowisko dotyczące specyficznego zbioru nieinstrumentalnych oczekiwań sensomotorycznych konstytuujących doświadczenia cielesne. Jeżeli ten rodzaj wiedzy proceduralnej, który zaproponowałam, nie zostanie uznany za ważny dla podejścia enaktywistycznego, w takim razie niech obrońcy tego podejścia przedstawią alternatywę, która będzie testowalna empirycznie.

Może to być jednak zadanie niemożliwe do wykonania. Jak zauważyliśmy, podważenie znaczenia ruchów sięgania, wskazywania, chwytania i drapania zakłada rozróżnienie między dwoma rodzajami wiedzy proceduralnej (konstytutywnym i instrumentalnym), a przez to rozróżnienie między dwoma systemami działania, z których jeden jest konstytutywnie związany z doświadczeniami percepcyjnymi, a drugi - nie. Skoro występują takie podwójne systemy sensomotoryczne, powinno być łatwo je rozdzielić, można jednak zastanawiać się nad tym, jak jeden system sensomotoryczny może zostać uszkodzony przy jednocześnie zachowanym drugim systemie. Dla odmiany enaktywista musi postulować istnienie unikalnego systemu działania, ale takiego, który wykorzystuje dwa odrębne zbiory informacji przestrzennych dotyczących umiejscowienia wrażenia, z których jeden będzie identyczny z przestrzenną treścią doświadczeń cielesnych ${ }^{28}$. Na przykład w IGR położenie głaskanej ręki byłoby zakodowane jako dwa centymetry dalsze dla jednego typu działania w porównaniu z drugim. Stąd wykorzystywana przez system motoryczny informacja przestrzenna byłaby wewnętrznie niespójna. To zaś wydaje się bardzo mało prawdopodobne. O ile mi wiadomo, nie ma żadnego empirycznego potwierdzenia tego typu dysocjacji w obrębie systemu motorycznego. Jakiekolwiek ujęcie sensomotoryczne dotyczące właściwej lokalizacji wrażenia musi uwzględniać działanie, które precyzyjnie określa tę lokalizację w systemie sensomotorycznym. Natomiast wydaje się nieprawdopodobne, by mogły istnieć dwa odrębne systemy sensomotoryczne czy nawet dwa odrębne zbiory informacji przestrzennych wykorzystywanych przez system sensomotoryczny.

Podsumowując: zwolennicy podejścia enaktywistycznego albo twierdzą, że doświadczenia cielesne określane są przez przestrzenną „wiedzę, jak” zaangażowaną w ruchy sięgania i wskazywania, albo nie głoszą takiego twierdzenia. Jeżeli je głoszą, wówczas do najbardziej przekonującej wersji enaktywistycznego ujęcia doświadczeń cielesnych odnoszą się obawy, które przedstawiłam w tym tekście. Natomiast jeżeli nie twierdzą [jak wyżej], to ciężar do-

\footnotetext{
${ }^{28}$ Wiadomo, że te same informacje przestrzenne mogą być prezentowane w dwóch oddzielnych ramach odniesienia. To jednak różni się od posiadania dwóch zbiorów informacji przestrzennych.
} 
wodu spoczywa po stronie enaktywizmu, by dokonać rozróżnienia między wiedzą sensomotoryczną, która konstytuuje doświadczenie cielesne, a wiedzą sensomotoryczną, która tego nie powoduje. Idąc dalej, enaktywiści powinni zaproponować alternatywne podejście sensomotoryczne do kwestii doświadczeń cielesnych, które zakładałoby istnienie albo dwóch systemów sensomotorycznych, albo dwóch oddzielnych zbiorów informacji przestrzennych wykorzystywanych przez system sensomotoryczny. Z tego względu enaktywistyczne ujęcie doświadczeń cielesnych odznacza się poważnymi wadami. I jeżeli ujęcie to nie stosuje się do doświadczeń cielesnych, które na pierwszy rzut oka mogą wydawać się mało kontrowersyjnym przykładem, tym bardziej jest wątpliwe, czy będzie miało zastosowanie w przypadku doświadczeń wzrokowych.

Przypuszcza się, że wzrok na początku rozwinął się nie po to, by zapewnić świadome doświadczenia percepcyjne, ale by zapewnić dystalną kontrolę sensoryczną ruchów. Dopiero później w toku ewolucji, wraz z pojawieniem się coraz bardziej złożonych zachowań, widzenie zaczęło dostarczać wewnętrznych modeli świata przechowywanych w pamięci i dostępnych dla innych systemów poznawczych. Percepcja i działanie wymagają różnych przekształceń sygnału wzrokowego. Przykładowo działanie wymaga dopasowań on-line, podczas gdy percepcja, która pozwala nam na rozpoznawanie przedmiotów, związana jest z trwałymi własnościami wzrokowymi. Ponadto działanie wymaga tego, by przedmiot poddawany działaniu położony był względem działającego w obrębie jego egocentrycznej ramy odniesienia, podczas gdy nie ma takich wymagań co do percepcji, w ramach której można wydawać allocentryczne sądy dotyczące względnych położeń dwóch przedmiotów. Różnice te skutkują ewolucją dwóch systemów wzrokowych, które najczęściej pozostają w interakcjach, ale można je rozdzielić.

Podobnie wydaje się, że przetwarzanie informacji cielesnych najpierw rozwinęło się w celu wykorzystania ich w działaniu. To, co jest potrzebne w działaniu, różni się pod wieloma względami od tego, co jest potrzebne w doświadczeniach cielesnych. Jako takie, te same informacje cielesne kodowane są $\mathrm{w}$ dwóch różnych formatach, a tylko jeden $\mathrm{z}$ nich jest powiązany $\mathrm{z}$ działaniem. Na przykład to, co jest potrzebne w działaniu, to stale aktualizowane informacje cielesne, tak by można było co jakiś czas znać położenie części własnego ciała. Dla odmiany - widzieliśmy, że w badaniach nad IGR uczestnicy ciągle doświadczają własnej dłoni jako położonej bliżej gumowej po tym, gdy nią poruszą. Pokazuje to, że ich doświadczenie cielesne nie było aktualizowane przez informacje propriocepcyjne. Odkrycia te oznaczają między innymi to, że mamy do czynienia $z$ dwoma funkcjonalnie określonymi systemami somatosensorycznymi, które wchodzą w interakcje przez większość czasu, ale które można rozdzielić. Idąc dalej, można zasugerować, że prowadzą one do dwóch odrębnych, funkcjonalnie określonych reprezentacji ciała: schematu ciała dla działania (to znaczy informacji o ciele koniecznych dla ruchu, takich jak poło- 
żenie, rozmiar kończyn, siła) oraz obrazu ciała dla percepcji (czyli sądu o własnych właściwościach cielesnych). Dysocjacje pomiędzy dotykiem a propriocepcją pokazują, że widzenie nie stanowi wyjątku w architekturze umysłu. Pozostałe modalności, włącznie z dotykiem i propriocepcją, wykorzystują podwójne kodowanie oparte na funkcjonalnej różnicy między percepcją a działaniem. Mózg koduje informację w różnych formatach, a sposób, w jaki ją wykorzystuje, określa sposób jej kodowania.

\section{Literatura}

Anema, H.A. i in. 2009. A Double Dissociation between Somatosensory Processing for Perception and Action, Neuropsychologia, xlvii, 6 (May 2009): 1615-20.

Block, N. 2005. Review of Alva Noë 'Action in Perception'. Journal of Philosophy, cii, 5, (May 2005): 259-72.

Botvinick, M. i Cohen, J. 1998. Rubber Hands 'Feel' Touch that Eyes See, Nature, cccxci (February 19, 1998): 756.

Clark, A. 2008. Supersizing the Mind. New York: Oxford.

Gangopadhyay, N. i Kiverstein, J. 2009. Enactivism and the Unity of Perception and Action. Topoi, xxviii, 1(2009): 63-73.

Hurley, S. 1998. Consciousness in Action. Cambridge: Harvard.

Jacob, P. 2008. The Scope and Limits of the Enactive Approaches to Visual Experiences. Perception, xxxvii, 3 (February 2008): 446-61.

Jacob, P. i Jeannerod, M. 2003. Ways of Seeing: The Scope and Limits of Visual Cognition. New York: Oxford.

Jeannerod, M. 1997. The Cognitive Neuroscience of Action. Cambridge: Blackwell.

Kammers, M.P., de Vignemont, F., Verhagen, L. i Dijkerman, H.C. 2009. The Rubber Hand Illusion in Action, Neuropsychologia, xlvii, 1 (January 2009): 204-11.

Kammers, M.P., van der Ham, I. J. i Dijkerman, H. C. 2006. Dissociating Body Representations in Healthy Individuals: Differential Effects of a Kinaesthetic Illusion on Perception and Action, Neuropsychologia, xliv, 12(2006): 2430-36.

Lackner, J.R. i DiZio, P.A. 2000. Aspects of Body Self-Calibration, Trends in Cognitive Sciences, iv, 7 ( July 1, 2000): 279-88.

Merleau-Ponty, M. 1945. Phénoménologie de la perception. Paris: Gallimard / 2001. Fenomenologia percepcji. Przeł. M. Kowalska i J. Migański. Warszawa: Wydawnictwo Aletheia.

Milner, D. i Goodale, M. 1995. The Visual Brain in Action. New York: Oxford / 2008. Mózg wzrokowy w działaniu. Przeł. G. Króliczak. Wydawnictwo Naukowe PWN.

Noë, A. 2004. Action in Perception. Cambridge: MIT. 
Noë, A. 2010. Vision without Representation. M. Madary i F. Spicer, red. Gangopadhyay, Perception, Action, and Consciousness: Sensorimotor Dynamics and Two Visual Systems. New York: Oxford: 245-56.

O'Regan, J.K. i Noë, A. 2001. A Sensorimotor Account of Vision and Visual Consciousness. Behavioral and Brain Sciences, xxiv, 5 (October 2001): 939-1031. Zob. komentarze do artykułu. / 2008. Sensomotoryczne ujęcie widzenia i świadomości wzrokowej. Przeł. A. Gruszka. A. Klawiter, red. Formy aktywności umysłu. Emocje, percepcja, świadomość. Warszawa: Wydawnictwo Naukowe PWN.

Paillard, J., Michel, F. i Stelmach, G. 1983. Localization without Content: A Tactile Analogue of 'Blind Sight'. Archives of Neurology, xl, 9 (1983): 548-51.

Rossetti, Y. Rode, G. i Boisson, D. 1995. Implicit Processing of Somaesthetic Information: A Dissociation between Where and How? Neuroreport, vi, 3 (February 1995): 50610.

Siewert, Ch. 2005. Attention and Sensorimotor Intentionality. D. Woodruff Smith i A.L. Thomasson, red. Phenomenology and Philosophy of Mind. New York: Oxford: 27094.

Thompson, E. 2005. Sensorimotor Subjectivity and the Enactive Approach to Experience. Phenomenology and the Cognitive Sciences, iv, 4: 407-27.

\begin{abstract}
The enactive approach aims at providing a unified account of perceptual experiences in terms of bodily activities. Most enactive arguments come from the analysis of visual experiences (Noë, 2004), but there is one domain of consciousness where the enactive theses seem to be less controversial, namely, bodily experiences. After drawing the agenda for an enactive view of tactile experiences, I shall highlight the difficulties that it has to face, both conceptual and empirical.
\end{abstract}

Keywords: enactivism; bodily experience; perception; action; touch. 